\title{
Coaching and feedback in the exercise periods of advanced studio voice lessons
}

\section{Coaching e feedback durante os exercícios iniciais em aulas de voz de nível avançado}

Kim Burwell * University of New South Wales (UNSW), Australia k.burwell@unsw.edu.au

\footnotetext{
* Kim Burwell is Senior Lecturer in Music, School of the Arts and Media, and Course Convenor for Music Pedagogy at the University of New South Wales (Australia). She is the author of Studio-based instrumental learning, Farnham: Ashgate, 2012. She is also a researcher in advanced studio teaching, and student approaches to personal practice; and a PhD supervisor in music performance, pedagogy and psychology.
} 


\section{Resumo}

O objetivo deste trabalho é caracterizar a interação entre professor e aluno no ensino e aprendizagem vocal durante os exercícios iniciais em aulas de voz de nível avançado. Um professor especialista de canto foi observado em aulas individuais com seis estudantes de graduação e gravações em vídeo das aulas são descritas e interpretadas em termos de comportamento colaborativo, com especial referência ao coaching e ao feedback. Os resultados apontam para procedimentos de natureza instrutiva, ou seja, com o professor dominando o diálogo verbal e direcionando a atividade dos alunos juntamente com procedimentos multimodais nos quais o professor baseia-se nas comunicações verbal, vocal e gestual para dar suporte ao aprendizado do aluno. Argumenta-se que a natureza complexa e desafiadora do aprendizado e do ensino de voz de nível avançado dá origem a práticas especializadas que devem ser abordadas e compreendidas no seu contexto específico.

Palavras-chave: Comportamento em aula individual. Ensino e aprendizagem vocal e instrumental. Educação musical de ensino superior.

\section{Abstract}

The aim of this paper is to characterise the interaction between teacher and student as they engage in vocal teaching and learning in the exercise periods of advanced studio lessons. An expert voice teacher was observed in one-to-one lessons with six undergraduate students, and films of their lessons are described and interpreted in terms of collaborative behaviour, with special reference to coaching and feedback. The findings describe procedures that are highly instructive, with the teacher dominating verbal dialogue and directing the students' activity, along with multimodal procedures in which the teacher draws on verbal, vocal and gestural communication to scaffold student learning. It is argued that the complex and challenging nature of advanced vocal studies gives rise to specialist practices that should be approached and understood on their own terms.

Keywords: One-to-one lesson behaviour. Vocal and instrumental teaching and learning. Higher music education. 


\section{Introduction}

Studio-based lessons are held to be of central importance for advanced studies in vocal and instrumental performance, with one-to-one tuition "the bedrock of higher music education" (GAUNT, 2013, p. 50-51). The studio, deeply rooted in traditions of apprenticeship, has the potential to offer each student the personalised attention of an expert in the field over an extended period, thus supporting technical, musical and personal development while maintaining "the strong cultural heritage of professional music education" (AEC, 2010, p. 40). However, the isolated setting of the studio has been described as problematic: the setting that offers privilege of access to individual students places an obvious constraint on the development of shared pedagogies, and has often led to a lack of transparency for other practitioners and researchers (BENNETT, 2012; BURWELL, 2005; BURWELL et al., 2017; CAREY et al., 2013; GAUNT, 2008; MCPHAIL, 2010; WEST; ROSTVALL, 2003).

Since the late twentieth century, researchers and practitioners have contributed to a rapidly expanding body of literature about studio practices. A review of pedagogy texts by Hoch and Sandage (2018) cites Miller (1986) and Bunch (1982; 5th edn DAYME 2009) among the landmark resources grounded in practical voice science, that are widely disseminated among practitioners. Nafisi also refers to Miller and Dayme, among others, as offering guidance for the content and structure of lessons, but notes that "there is surprisingly little material about the ways in which all this may be communicated to a student" (2013, p. 348). Duke and Simmons make a similar point about the non-research literature on music teaching, which tends to be focused on instructional materials, music repertoire, performance practice, and technique, "rather than explaining the process of effecting behavior change in learners" (2006, p. 9). Kiik-Salupere and Ross add that there is a scarcity of research into the nature of teaching methods in voice lessons, attributing this to the "personal character" of teacher-student interactions and cultural differences between studios (2011, p. 405).

Advanced studio teaching is, then, complex and specialist, in a setting characterised by isolation. Jørgensen, discussing higher music education from the perspective of quality improvement, argues that "we must engage in descriptions, discussions and reflection about what is going on" in the studio, so that individual experiences can be related to broader viewpoints (2009, p. 111). The broad aim of this paper is to contribute to such discussions by describing and reflecting on the interaction between voice teacher and student, with particular focus on the exercise or warm-up periods of advanced studio lessons.

\section{Literature review}

An increasing amount of research has begun to investigate the nature of interactions in studio lessons without necessarily distinguishing between singers and instrumentalists, and this work has employed a wide range of methodological approaches to highlight different aspects of the subject. For example, the perceptions and attitudes of lesson 
participants have been sought through a survey of high-school pupils, university students and professional singers (KIIK-SALUPERE; ROSS, 2011), and mixed groups of singers and instrumentalists have participated in interviews and focus groups, encouraged to engage in "storytelling and reflection" (CAREY; GRANT, 2015, p. 7). In other studies, interviews have been used in conjunction with video observation, to collect richer data about studio participants' own understanding of their practices (BURWELL, 2012; BURWELL, 2016a; JAMES et al., 2010; JOHANSSON, 2013). Studies based on observation alone have employed varying units of analysis, again casting light onto varying aspects of the subject: thus Kennell (2010) profiles teacher-student interactions through the random sampling and categorisation of lesson behaviour, while Nerland (2007) uses participant observation and discourse analysis to characterise studio teaching as a cultural practice.

The relatively late flourishing of research focused on studio lessons has meant that often, research tools and theoretical premises have been adopted from the field of general education, with researchers gradually recognising and testing the assumptions that might come with them, and gradually identifying the nature and demands of the more specialist area (BURWELL, 2012, p. 59). For example, high ratios of positive to negative feedback have been linked to successful classroom practice in many disciplines, but Duke and Henninger $(1998,2002)$ found that in studio lessons, participant and observer attitudes remained positive in the light of negative feedback. They suggest that verbal correction "may be inconsequential in situations in which students have frequent performance opportunities" (1998, p. 491), in that performance success itself can constitute positive feedback for the student (p. 484). A further example of borrowing from general education comes from the scaffolding theories devised in the 1970s and 1980s to explain how an adult can help a child to learn through specifically ordered strategies - recruitment of attention, task simplification, direction maintenance, marking critical features, frustration control, and demonstration (WOOD; BRUNER; ROSS, 1976). When Kennell $(1997,2002)$ sought these scaffolding strategies in the context of undergraduate performance studies, he found the fixed order and several of the strategies ill-suited to the more specialist, more adult context; he characterises studio lessons, rather, as "a succession of problem solving events", devising his own "teacher attribution theory" to explain the quickly responsive nature of lesson behaviour (2002, p. 246).

That there should be theories specifically tailored for studio lessons is consistent with the work of Schön $(1983,1987)$ who called for the development of an epistemology of practice to explain the artistry of professionals in action. Emphasising, like Kennell, the contingent processes involved in practical teaching environments, Schön describes a continual restructuring of "strategies of action, understandings of phenomena, or ways of framing problems" (1987, p. 28). Such improvisatory approaches are complemented by the routines described by Shulman (2005) in terms of the "signature pedagogies" that have evolved to reflect the distinct values and practices of professionals working in specialist areas of education. Shulman emphasises the complexity of pedagogies that bridge theory and practice, and argues that the "routine of pedagogical practice", devised for each specialist area, "cushions the burden of higher learning"; habits offer the advantage of scaffolding the learning process, though they can also lead to rigidity 
and perseveration (p. 56). Routines and habits must be acquired, and it follows that participation in studio lessons is a skill in itself, to be learned and developed. Mehan (in LAVE, 1993, p. 20) explains that the workings of social structure are evident in participant interactions, and this implies a social constructionist perspective on the activity of teacher and student as they collaborate to construct studio behaviour (BURWELL, 2010; 2012).

The texture of studio behaviour consists in both talk and performance, and the contributions of teacher and student are typically asymmetrical. In an undergraduate voice lesson studied by Burwell (2016a), for example, the ratio of teacher-student singing - measured in seconds - was 9:91, while the ratio of teacher-student talk measured in wordage - was 86:14. This was not taken to be evidence that the student was passive, since in singing she was highly active; it was argued that the balance of behaviours is contingent on the agreed aims of any lesson, and might not be problematic unless one participant were to dominate in both areas (BURWELL, 2016b; 2018). Of course, specialist studio lessons also involve nonverbal behaviour: in studies by Nerland (2007) and Burwell (2012) this was regarded as more or less unconscious, and taken to reflect participant cultures and attitudes, but the conscious use of gesture can be a valuable teaching tool, particularly perhaps in vocal studies. Thus Nafisi (2010) analysed film footage of 18 advanced voice lessons, categorising the use of gesture among the technical, musical and sensation-related, and linking its importance to the "singularly challenging" nature of the vocal instrument, "substantially internal, not readily seen, and poorly innervated for sensory feedback" (p. 103). Howard (1982) concurs that voice training poses particular challenges, given the singer's "whole-part problem of embedding one facility within another in a structure of staggered progress":

...in other words, singing is a complex skill. Corresponding to this complex of facilities is a regimen of precisely aimed exercises and visual imagery, while working against them are difficult obstacles to self-observation and assessment. Accordingly, there is the necessity of establishing perceptual rapport between singer and trainer, particularly as regards the correlation of sensation and sound. (HOWARD, 1982, p. 6: emphasis original)

In establishing the kind of rapport Howard describes here, teachers may use gesture and imagery, alongside vocal or postural demonstration. The ability to explain vocal production - what Howard calls "accountable know-how" (1982, p. 69) - is to be expected in expert teachers, but Welch et al. add that while students may understand explanations, "it is a different challenge to be able to recognise these features and to manipulate and sustain optimal singing behaviour systematically" (2005, p. 232). The same authors make a strong case for the use of technology in studio lessons, arguing that real-time feedback can help to clarify shared perceptions and overcome the potential misunderstanding of metaphors. For Kiik-Salupere and Ross, however, the nature of the singer's instrument - "live, relatively unstable and influenced by the physical and psychological state of its 'player'" - makes the voice teacher "the most important reliable source of feedback for a voice student" (2011, p. 406). 
Vocal exercises: the "warm-up"

In the current study, characterising teacher-student interactions in advanced studio lessons, the "warm-up" period of lessons has been identified as an area for special attention because of its particular importance for singers and voice education. Gish et al. (2012), after a survey of voice students in higher education and professional singers, reported that a "regular vocal warm-up is considered essential by most singers, as described in the literature" (p. 5). The warm-up may be particularly important for pre-professional singers: Elliot, Sundberg and Gramming (1995) remark that "the warm-up appears to typically have a greater effect on the voice in such subjects compared with professional singers, who seem to be more or less constantly warmed up, perhaps because of the frequent use of their professional voice" (p. 38).

The physiological benefits of the vocal warm-up are not fully understood $(\mathrm{HOCH}$; SANDAGE, 2018, p. 79), though researchers have ascertained that it may regulate vibrato rate, and thus tone quality (MOORCROFT; KENNY, 2013a). The perceived benefits may differ between singer and listener (MOORCROFT; KENNY, 2013b), but a psychological benefit for the singer seems clear. Thus in an experiment conducted by Elliot et al. (1995) the physiological outcomes of warming up were variable, but all participants perceived that it was successful: "the subjects felt the voice timbre to be better, that it was easier to sing, particularly at high pitches, and that the voice appeared as a more obedient instrument" (p. 39). The term "warm-up" might imply an aim of maintenance only, on the general principle of reversibility, which holds that "the level of exercise intensity and frequency needs to be sufficient enough to prevent loss of these mechanisms that were upregulated with training"; but in pedagogical texts, vocal warm-ups are essentially focused on skill acquisition (HOCH; SANDAGE, 2018, p. 79-80). In the light of modern exercise physiology the content of warm-ups, which according to Titze once rested on "a few scales and arpeggios on a few selected vowels", is now more likely to involve "entire systems of carefully designed sequences of exercises" (2000, p. 2864).

The principle of sequenced skill acquisition again highlights the importance of warm-ups in studio lessons, in which "the very 'building of the instrument' constitutes a large part of the learning" (NAFISI, 2013, p. 347). "Voice building" has been associated with the reshaping of the student singer's identity, against a background of "study, young adulthood and university life" (O'BRYAN, 2015, p. 125), and this would seem to make the warm-up or exercise period significant within studio voice lessons, and perhaps unique among studio lessons in general.

\section{Research design and methods}

The broad aim of this paper is to characterise the interaction between teacher and student as they engage in vocal teaching and learning in the exercise periods of advanced studio lessons. Specifically, the research questions ask:

1. How is the exercise period in advanced voice lessons distinct from the study of repertoire?

2. How do teacher and student contribute to collaborative behaviour in the 
exercise periods of voice lessons?

3. How do coaching and feedback function in exercise periods?

In addressing these questions, the study explores the dynamics of lesson interactions through observation and micro-analysis in a small-scale case study, consisting in one teacher giving single lessons to six individual students. The case study is intrinsic rather than instrumental (STAKE, 2005, p. 445) with the emphasis lying on understanding the particular case rather than generalisation. Even so, qualitative case studies can suggest authentic possibilities in social practices, by describing "the very details of the participants' action" (PERÄKYLÄ, 1997, p. 215), and they can contribute to generalisation to other situations on conceptual grounds, rather than to whole populations on statistical grounds (RADLEY; CHAMBERLAIN, 2012; YIN, 1998).

Participants were identified through an appeal for volunteers among the teachers and students working in an undergraduate music programme in Australia. In keeping with the ethics protocols of the host institution, participants were involved through informed consent and were assured of anonymity in reporting. In this report the teacher will be known as Terrence and the students by pseudonyms as shown in Table 1 . The student participants are listed in order of increasing expertise, in terms of the number of semesters they had been studying at university by the time of filming; the table also shows the number of semesters they had been studying with Terrence in particular, and their next performance examination marks.

\begin{tabular}{|c|c|c|c|c|}
\hline Lesson & Student pseudonym & $\begin{array}{c}\text { Semesters of study at } \\
\text { university }\end{array}$ & $\begin{array}{c}\text { Semesters of study with } \\
\text { Terrence }\end{array}$ & $\begin{array}{c}\text { Exam mark in semester of } \\
\text { filming }\end{array}$ \\
\hline A & Alyssa & 2 & 2 & 59 (Pass) \\
\hline B & Bree & 2 & 2 & 61 (Pass) \\
\hline C & Courtney & 4 & 4 & 73 (Credit) \\
\hline D & Desmond & 4 & 4 & 86 (High Distinction) \\
\hline E & Esme & 6 & 2 & 83 (Distinction) \\
\hline F & Faye & 6 & 6 & 87 (High Distinction) \\
\hline
\end{tabular}

Table 1: Student participants

The participants were provided with a compact digital camera and managed the filming themselves. This was logistically convenient, since the lessons took place in the teacher's private studio, but it was also considered important to allow participants a degree of control over what would be filmed, and this had an effect on data collection in ways that should be acknowledged. In at least one case (Lesson E) it seemed clear that some lesson-related discussion had taken place before the camera was turned on; during Lesson $C$, the teacher turned the camera off temporarily (C, 49:20), evidently for a private discussion; and in two further lessons it was clear that discussion would continue after the end of the film (A, F). The lessons were expected to run for one hour each, and the camera battery should have been sufficient for that, but Lesson $C$ was scheduled to run for two hours, the film cutting off at 64:34. Film cuts were noted in places where the battery or memory card reached the end of their capacities, or where participants feared that they might, and so stopped the camera temporarily to check it 
(A, B, D). Finally, the Lesson E film was cut short unnoticed at $38: 18$, and the Lesson $B$ film started late because participants had forgotten to turn the camera on. In the final collection, the average length of lesson films was 3309 seconds, or just over 55 minutes, and the range 2307-3874 seconds.

In the analysis of film data, the verbal dialogue and musical content were transcribed, incidents of singing noted and timed, and gestures noted and described. The analysis was descriptive and interpretative, and was approached through the use of qualitative and quantitative tools, which Yin asserts is characteristic of "the most desirable case studies" (1998, p. 245). Qualitative information can be complemented and refined by numerical description, with "simple counts" clarifying terms such as "some, usually, or most" (MAXWELL, 2010, p. 476; emphasis original). Thus, to interrogate the data in terms of the research questions, verbal dialogue was quantified as wordage, and the relative contributions of teacher and student to verbal dialogue and singing were calculated. The time devoted to the varying musical content was also noted against the quantities of talk and singing involved in working through it. The level of description was then deepened by seeking patterns of behaviour in the use of questions and in the work on discrete vocal exercises, with particular reference to coaching and feedback.

\section{Findings}

\section{Distinguishing exercise periods}

Each of the lesson films begins with a period focused on exercise, followed by a longer period dominated by repertoire work. The exercise period occupies an average of $22.57 \%$ of the lesson time, but this must be regarded as a rough figure because not all of the films show complete lessons, as previously noted: Lessons $C$ and $E$ are cut short by the camera and Lesson B starts late.

The starting point for each of the two periods is clear in the verbal transcripts. The exercise period, from the beginning of the film, includes are some preliminary remarks that in all six cases refer to the camera: even when the film starts late, the teacher notes wryly "All right - so we've done about ten minutes of scales, because we forgot to turn the camera on, which was really good" (Lesson A, 00:00). In four of the lessons the teacher Terrence introduces the student for the benefit of the camera $(A, C, D, E)-$ for example, "So this is Esme Surname, soprano: soprano extraordinaire", at which the student laughs ( $E, 00: 19)$. Little else is said before work begins on the exercises, and in two of the lessons exercises are not mentioned at all before Terrence launches the first of them from the piano $(A, E)$. The preliminary remarks for the exercise periods last between 5 and 29 seconds, with an average of 20.17 seconds.

The preliminary remarks for the repertoire period are more variable and typically last longer - between 14 and 211 seconds, with an average of 86.67 seconds. In two of the lessons Terrence speaks almost as if the repertoire period were actually the beginning of the lesson - "Okay, so we're starting with..." (B, 07:20); "Now. How do you want to run this rehearsal?" ( $A, 18: 08)$. The content of the repertoire period sometimes includes vocalises that are treated as performance pieces in their own right $(A, B, C, E)$. In four of 
the lessons the student is invited to choose the order of the content, and in the other two Terrence expresses his own choice with the intonation or form of a question - "Okay, so we're starting with the Portamento, which is the vocalise?" (B, 07:21); "So, should we just drill the Marchesi...?" (E, 11:03). This is worth noting because it forms a contrast with the exercise period, which begins without reference to either the projected order or the student's preferences. Nor is the purpose of the exercise period made explicit, though Terrence sometimes refers to it rather loosely in terms of warming up $(B, 10: 18 ; C, 00: 11$, 09:53; D, 00:24, 15:12).

The exercise and repertoire periods are distinguished from each other in the relative quantities of verbal and singing behaviour. Comparing average figures would be misleading because some of the lesson films are incomplete, but the density of these behaviours is revealing. Over the six lessons, verbal dialogue in the exercise period occurs at an average rate of 75.14 words per minute, and in the repertoire periods at 93.54 words per minute; balancing that, singing is heard for $66.75 \%$ of the time in the exercise period, and $47.15 \%$ in the repertoire period. The exercise period is thus one of relatively low verbal activity, and high levels of singing.

The balance of activity between teacher and student also varies between the exercise and repertoire periods, as shown in Table 2 . In both periods, the teacher dominates verbal dialogue while the student dominates singing activity, but the contrast between their contributions is particularly marked in the exercise period.

\begin{tabular}{|c|c|c|}
\hline & Talk (\% of total wordage) & Singing (\% of time) \\
\hline Exercise period & & 16.94 \\
\hline Teacher & 90.73 & 83.06 \\
\hline Students & 8.99 & \\
\hline Repertoire period & & 28.69 \\
\hline Teacher & 83.92 & 71.31 \\
\hline Students & 16.08 & \\
\hline
\end{tabular}

Table 2: Talk and singing from teacher and students, in exercise and repertoire periods

\section{Characterising the exercises}

In the exercise period teacher and students work through a set of motivic exercises. These are accompanied by Terrence at the piano, who plays a rhythmic figure with repeated chords from the right hand and single notes or octaves from the left; there is no discernible pedalling. The rhythmic figure introduces each motif by effecting a semitonal shift, and the accompaniment tends to give way as the motif is sung, leaving at least one of the teacher's hands free for gestures. Twelve different exercises can be identified in the exercise period, but there is a core of nine that occur in almost all of the lessons, always in the same order. Occasionally an exercise might be omitted, or more rarely, repeated, and the Lesson B film starts late with Exercise 8 . The exercises vary in tempo, articulation and syllables, and gradually ascend or descend toward the extremes of each student's vocal range.

Characteristics of the nine core exercises are shown in Table 3. The exercise list 
is consistent, with a few exceptions. Because the Lesson B film starts late, Exercise 9 is the only one appearing in all six lessons; Exercise 7 is omitted in Lessons $B$ and $D$, and Exercise 8 is omitted in Lessons $C$ and $D$; and Lessons $B$ and $C$ each include two exercises that are additional to the core nine, and do not appear in other lessons. The second column of Table 3 shows the number of lessons in which each exercise appears, and the third column shows the average number of motifs sung.

\begin{tabular}{|c|c|c|c|c|c|c|}
\hline Item & Lessons & Motifs & Syllables & Pitch & Range of motif & Sequence \\
\hline Ex 1 & 5 & 68 & Mm-Ah & Slow repeated note & & Descending \\
\hline Ex 2 & 5 & 56 & (Nugget $x$ 8) Nah & Arpeggio & $\begin{array}{c}\text { Up \& down over } \\
\text { a 10th }\end{array}$ & Ascending \\
\hline Ex 3 & 5 & 75 & Ha hoo ha hoo hah & Arpeggio & $\begin{array}{c}\text { Up \& down over } \\
\text { a 5th }\end{array}$ & Ascending \\
\hline Ex 4 & 5 & 68 & $\begin{array}{c}\text { Moo neh moh neh } \\
\text { mee }\end{array}$ & Repeated notes & & Descending \\
\hline Ex 5 & 5 & 89 & Noo-oo & Portamento & $\begin{array}{c}\text { Falling through } \\
\text { a 5th }\end{array}$ & Ascending \\
\hline Ex 6 & 5 & 52 & La (loie x 7) lah & Arpeggio & $\begin{array}{c}\text { Up \& down over } \\
\text { a 10th }\end{array}$ & Ascending \\
\hline Ex 7 & 4 & 64 & Noie-Ah & Passing notes & $\begin{array}{l}\text { Up \& down twi- } \\
\text { ce over a 3rd }\end{array}$ & Ascending \\
\hline Ex 8 & 4 & 75 & (Zoie x 3) zah & $\begin{array}{c}\text { Melodic figure based } \\
\text { on 3rds }\end{array}$ & $\begin{array}{c}\text { Up \& down over } \\
\text { a 5th }\end{array}$ & Ascending \\
\hline Ex 9 & 6 & 190 & $\begin{array}{c}\text { Noh-ie, or Nah-oie- } \\
\text { Ah, or Zoie-Ah }\end{array}$ & Arpeggio & $\begin{array}{c}\text { Up \& down over } \\
\text { a } 5 \text { th }\end{array}$ & Ascending \\
\hline
\end{tabular}

Table 3. Characteristics of the nine core exercises.

The sequence of exercises shows a gradual evolution of demands on the student singers. Thus Exercise 1 is the simplest and least demanding; the next two emphasise agility, with number 2 the only exercise that has two syllables per note, and number 3 sung staccato. Exercise 4 has the same pitch content as number 1, with the added challenge of changing syllables; and Exercise 6 has the same pitch content as number 2, with the added challenge of diphthongs. Exercises 7, 8 and 9 add no further demands in terms of pitch or agility, becoming more tuneful and perhaps allowing more attention to be paid to legato and tone quality. In Exercise 9 the syllables are altered for individual students; the same exercise stands out for the average number of motifs sung - more than double any of the other exercises. Compared with the early core exercises, number 9 thus supports a more substantive and personalised exploration of each developing voice.

\section{Characterising the exercise period}

Work on the exercises includes singing and talking, and accounts for $89.50 \%$ of the time in the exercise period, while the rest is dominated by verbal dialogue. The "off-task talk" includes the preliminary remarks already mentioned, and brief references to the camera that recur from time to time - for example, when Terrence says "I think we need you over there - I don't think they can see you there" (B, 02:10). Elsewhere, Courtney reports on a busy week that has left her tired $(C, 07: 05)$, and Alyssa and Terrence discuss 
the possibility of a social meeting when her parents visit ( $A, 08: 09)$. In addition, there are two more substantial interludes in which Esme and Faye describe issues that have arisen in rehearsals with their accompanists, since the last lesson ( $E, 02: 13 ; F, 09: 46)$.

In keeping with the teacher's dominance of verbal dialogue, Terrence asks $95.48 \%$ of the questions that appear in the exercise period, and few of them encourage verbal responses from the students. Thus $56.77 \%$ of his questions are commands expressed with the intonation or form of a question - for example, "Swing those arms?" (A, 00:14) and "Can you do it again?" (B, 03:28). Other redundant questions occur when tails such as "all right?" or "you know?" are added to statements. Genuine inquiries are made in $32.90 \%$ of Terrence's questions, and these usually require short and limited answers for example, "Do you know what I'm saying?" (F, 05:55) and "Did you warm up before you came in?" (A, 01:04). In four of the lessons Terrence asks a series of such "genuine" questions, seeking background information about the student's fatigue ( $C$, from 06:57, 4 questions) or accompanist ( $E, 02: 51,5$ questions); or helping the student to identify the next exercise ( $A, 14: 50,5$ questions) or to reflect on her own strengths and weaknesses (B, 04:19, 3 questions).

Occasionally Terrence uses a querying tone for statements that might be challenging for students to understand, as if he is simultaneously asking them whether they understand - for example, "So we're just going into your head resonance, that's getting your head voice activated?" (F, 02:10). On two occasions, students use a similar tone when responding to challenging questions. Thus Bree, when asked to identify her strengths and weaknesses, replies "At the top is the strength?" (B, 04:26); while Faye, asked about a refinement to her technique, tentatively asserts "It's like it makes me feel more a part of the music as well?" (F, 09:35). There are few other questions from students. Four of them are simple - including for example "What note was that?" (F, 02:47) and "Pardon me?" (D, 04:15). There is only one example of a more searching inquiry for Terrence, when Desmond asks "What do you mean, a double Oh?" (D, 08:45): in spite of the apparent rarity of such an event, Terrence responds with "Good question!" - and goes on to discuss and demonstrate his point at some length.

\section{Identifying behavioural loops}

The structure of the period rests on the series of exercises, which are given a characteristic treatment: Terrence initiates each exercise verbally and with a piano cue, often reinforcing the first few notes of singing before giving way to the student. He coaches the student, and when the exercise is finished, he offers some feedback before proceeding to the next exercise. "Coaching" in this context refers to the remarks made during work, and it tends to be directive in nature, though it includes immediate responses to the student's singing. "Feedback" is defined here by its concluding function, and tends to be more expansive and reflective, with broader responses to the student's work. An example of a loop of behaviour appears in Table 4, with coaching from 00:16 and feedback at 01:16. 


\begin{tabular}{|l|l|l|}
\hline Time & \multicolumn{1}{|c|}{ Teacher talk / SINGING (seconds) } & Student talk / SINGING \\
\hline $00: 05$ & So let's go to "zoie" in the soft palate. & \\
\hline $00: 10$ & SINGS (2) & SINGS (66) \\
\hline $00: 16$ & Yes. Soft palate, drop jaw. & \\
\hline $00: 22$ & Yeah, right back there & \\
\hline $00: 28$ & Yes, drop the jaw as you go. & \\
\hline $00: 36$ & SINGS (2) & \\
\hline $01: 10$ & That's really good. & \\
\hline $01: 16$ & $\begin{array}{l}\text { The pitch is not always accurate; but the tone is developing, you know. } \\
\text { Good. }\end{array}$ & \\
\hline
\end{tabular}

Table 4: Extract from Lesson B. Singing is indicated by shaded areas.

The loops of exercise work account for $89.50 \%$ of the time in the exercise period, and $76.67 \%$ of the verbal dialogue. Almost all of the singing is devoted to exercise work: the exception is Lesson C, in which there is a total of 12 seconds' unrelated humming while teacher and student organise their scores. The core of nine exercises is shown again in Table 5, showing the average time devoted to each exercise alongside singing and wordage.

\begin{tabular}{|c|c|c|c|c|}
\hline & $\mathbf{n}$ & Time (seconds) & Singing (seconds) & Talk (wordage) \\
\hline 1 & 5 & 53 & 46 & 27 \\
\hline 2 & 5 & 58 & 54 & 42 \\
\hline 3 & 5 & 44 & 40 & 15 \\
\hline 4 & 5 & 42 & 37 & 20 \\
\hline 5 & 5 & 59 & 46 & 54 \\
\hline 6 & 5 & 60 & 46 & 63 \\
\hline Average, Ex 1-6 & & 52.57 & 44.80 & 36.93 \\
\hline 7 & 4 & 75 & 63 & 50 \\
\hline 8 & 4 & 142 & 85 & 136 \\
\hline 9 & 6 & 197 & 122 & 318 \\
\hline Average, Ex 7-9 & & 137.88 & 89.93 & 167.83 \\
\hline
\end{tabular}

Table 5: Core exercises showing average time spent, singing and talk

Table 5 shows no clear trends across the first six exercises, but for exercises 7 , 8 and 9 there are some dramatic increases: in terms of time spent and singing, the average figures for Exercises 1-6 are roughly doubled for exercises 7-9 (by 2.62 and 2.01 respectively), and for wordage they increase by more than four times (4.54).

The increase of wordage may be linked to the loops of behaviour for each successive exercise, particularly in terms of the feedback that normally closes each loop, as shown in Table 6. 


\begin{tabular}{|c|c|c|c|c|c|c|}
\hline & Lesson A & Lesson B & Lesson C & Lesson D & Lesson E & Lesson F \\
\hline Ex 1 & 1 & & 3 & 2 & 4 & 1 \\
\hline Ex 2 & 3 & & 1 & 8 & 0 & 2 \\
\hline Ex 3 & 3 & & 5 & 1 & 1 & 15 \\
\hline Ex 4 & 4 & & 1 & 15 & 1 & 1 \\
\hline Ex 5 & 1 & & 2 & 72 & 12 & 20 \\
\hline Ex 6 & 6 & & 46 & 1 & 8 & 1 \\
\hline Ex 7 & 2 & & 9 & 13 & 14 & 44 \\
\hline Ex 8 & 32 & 14 & & & 13 & 33 \\
\hline Ex 9 & $12+84=96$ & 63 & 48 & 67 & 39 & 72 \\
\hline
\end{tabular}

Table 6: Wordage of teacher feedback closing each of the core exercise loops

Each figure in Table 6 shows the wordage for the feedback that closes the exercise loop, and each exercise is managed in a single loop, with one exception: this is a double loop in Lesson A, where Exercise 9 is worked twice - first leading to 12 words, and then leading to 84 words of feedback. Once again, the figures eventually increase as the core exercises go on. The average wordage of feedback for Exercises 1-6 is 8.43 words, while the average for Exercises 7-9 is 34.81, more than four times as much (4.13). Thus in terms of time spent, along with the amounts of singing, verbal dialogue and feedback, the exercise loops move through a broadly enlarging spiral of activity.

\section{Characterising coaching}

In addition to playing the piano accompaniment, Terrence supports student singing through coaching, which may be verbal, vocal or gestural. Verbal coaching while the student is singing typically consists of instructions - for example "Start higher to drop"; reminders - "Keep swinging, yeah?"; encouragement - "Risk it, risk it: next one"; or approval - "Good" (C: 02:27, 10:27, 14:44, 14:59). Such comments are offered immediately after a vocal motif, while Terrence is playing the piano cue for the next one. Presumably the time constraint, the need for the student to grasp information quickly, and the demands on Terrence's own concentration combine to keep these coaching comments brief, simple and positive. Verbal support is also offered between exercise performances, and even without the musical constraint on timing it often retains the same characteristics, being concise and direct, though the grammar is often tidier. This approach gives an intense momentum to the exercise loops, broken only occasionally by the "off-task" talk previously mentioned, and giving the plateaus of feedback a sense of arrival.

Terrence also uses singing as a tool for coaching. Of all the incidents of Terrence singing, more than half (58.06\%) consist in reinforcements of the student's own singing by starting the exercises, or some of the motifs within them, at the same time as the student. Often too (13.36\%) he begins to sing an exercise to cue the student, and the singing can become part of a command - for example, "So let's go just forward only: can you do [SINGS, 2 seconds]" (A, 02:12). Aside from some unrelated humming, the remaining incidents of Terrence singing (26.73\%) are demonstrations. These might be simple, reminding the student of what to do without being a rhythmic cue - for example, "Can 
we just do this one? [SINGS, 4 seconds]" (B, 06:27). Demonstration can also support more complex requests. The example shown in Table 7 is characteristically embedded in a multi-modal explanation, as Terrence draws on vocal, verbal and gestural tools to convey his meaning to a student working on Exercise 9.

\begin{tabular}{|l|l|l|}
\hline Time & \multicolumn{1}{|c|}{ Talk / SINGING (time) } & \multicolumn{1}{c|}{ Action } \\
\hline $07: 32$ & Stay in "Ah": keep the elongation & Right hand raised \\
\hline $07: 34$ & SINGS (2 seconds) & Hands brought together in prayer position, elbows out \\
\hline $07: 36$ & Lengthen to that opening, so, so & Right hand on breast, left hand raised to brow \\
\hline $07: 38$ & SINGS (2 seconds) & Left hand raised further; right hand rises to meet it, then falls away. \\
\hline $07: 40$ & One breath. & \\
\hline
\end{tabular}

Table 7. Teacher talk, singing and gesture in Lesson $\mathrm{D}$

Demonstrations are distinct from cues in that although both may include verbal information, demonstrations apparently are not intended to lead to an immediate vocal response from the student. Occasionally, however, a demonstration seems to be mistaken for a cue, in that the student joins in singing rather than attending fully to the teacher's example, as shown in Table 8.

\begin{tabular}{|c|l|l|}
\hline Time & \multicolumn{1}{|c|}{ Teacher talk / SINGING (time) } & Student talk / SINGING (time) \\
\hline $09: 19$ & You're a bit & \\
\hline $09: 20$ & SINGS (1 second) & \\
\hline $09: 21$ & Don't worry about the final note; think of the process to the note - like & \\
\hline $09: 26$ & SINGS (4 seconds) & \\
\hline $09: 27$ & & SINGS (3 seconds) \\
\hline
\end{tabular}

Table 8. Talk and singing in Lesson A

The use of gesture as a tool for coaching is so consistent that there is only one instance of an exercise supported by no gesture at all (Lesson C, Ex 1). Gestures are distinguished from other movements in that they appear to be conscious, though they may be more or less deliberate and more or less focused. The simplest gestures are cues that Terrence gives with one hand, immediately after the piano figure that introduces each vocal motif. These are often perfunctory, and since the piano cue is always present, they may be redundant, though perhaps they convey a sense of the teacher's engagement and energy. Often Terrence's gestures are more extended, as if conducting. For example, the Exercise 5 motif falls portamento through a perfect fifth, and whenever that exercise occurs Terrence swirls his hand to match the musical and perhaps physical aspects of the descent.

Five of the six students fall in with this behaviour at times and conduct themselves, without prompting from Terrence: the exception is Esme, who though a relatively experienced student, has been studying with Terrence for only two semesters. There are also student gestures that evidently form an essential part of the vocal exercises, with the dynamic of the movement implicated in the vocal procedure. The most common 
of these involves a deep knee-bend as the arms swing forward and straight, the knees descending as the motif rises. This gesture is always employed in Exercises 2 and 6, which are based on agile arpeggio motifs, and it often occurs elsewhere. Terrence sometimes asks for refinements, as for example in Lesson D: "Keep the hands out, the lower you go - keep them out? - Okay, so that's a better commitment to that" (D, 02:09, Exercise 2). In three of the lessons Terrence leaves the piano to demonstrate and explain the detail and function of the gesture (A, Exercise 8; C, Exercise 9; D, Exercise 2).

Gesture for either a musical or physical aspect of the vocal exercise is distinct from gesture as a metaphor for the concepts of vocal production, which Terrence uses to enhance his demonstrations or verbal explanations. An example from Exercise 9 appears in Table 9.

\begin{tabular}{|c|c|c|}
\hline Time & Talk / SINGING (time) & Action \\
\hline \multirow[t]{3}{*}{ 03:03 } & $\begin{array}{l}\text { Now, can we do the one where you go } \\
\text { forward, }\end{array}$ & \\
\hline & & Left arm points forward, over the piano \\
\hline & $\begin{array}{l}\text { and then swing it back, across the roof of the } \\
\text { mouth, okay? }\end{array}$ & $\begin{array}{l}\text { Left arm again forward, with right arm drawing } \\
\text { back - almost as if preparing to fire an arrow }\end{array}$ \\
\hline 03:08 & SINGS (3 seconds) & $\begin{array}{l}\text { "Arrow" gesture repeated. After the peak of the motif } \\
\text { the hands descend with a circular movement at the } \\
\text { wrists }\end{array}$ \\
\hline
\end{tabular}

Table 9: Teacher talk, singing and gesture in Lesson B

Such metaphorical or conceptual gestures are highly varied and appear to be improvised to meet the needs of the moment, but there is a common principle of gesturing away or downward as a motif rises, and Terrence uses a recurring gesture of swirling one hand around the side of his skull as he demonstrates $(B, 06: 42 ; C, 08: 44$; $\mathrm{F}, 04: 32)$. The conceptual use of gesture does not occur at all in the work on Exercises 1, 2 and 3, and first appears in Exercises 4, 5 and 6 in Lesson A - that is to say, in the lesson of the first-year student Alyssa. The remaining exercises show an increasing use of metaphorical gesture, for Exercises 7 and 8 (in three of the four lessons that have those exercises), and 9 (in all six lessons). This suggests that metaphorical gesture is being used to support areas in progress for the students, and that the set of exercises becomes more challenging conceptually as it goes on.

\section{Characterising feedback}

By the definition adopted for the purposes of this paper, feedback reflects on and concludes work on any particular exercise. There are, of course, features of feedback that also occur during the coaching phases of the work, and the most obvious is the use of nonspecific praise. This is characteristic of the feedback for the first few exercises, which is minimal: no student receives specific feedback on Exercise 1, and Courtney completes as many as five exercises with only nonspecific praise - "Yeah, good good" (02:07), "Good" (03:21), "Good! Good good good" (04:16), "Good" (05:01) and "That's it" $(05: 47)$. In the case of these monodimensional remarks the difference between 
coaching and feedback is nominal - a matter of distinguishing between present and past tense - and it hardly seems worth trying to establish whether they refer to what the student is doing in the moment, or to the whole of an exercise loop just completed.

The more idiomatic feedback, however, is more explicit. Even concise praise can convey information - for example, "Nice and forward - great" (A, 04:12, Exercise 4), and on several occasions Terrence uses it to observe the effects of the exercise process for example, "Beautiful, beautiful: so the top is starting to happen" (C, 08:39, Exercise 7). The same specific effect is noted in two other lessons - "Oh the top is really really improving" ( $E, 08: 46$, Exercise 8); "So the top is really, really really developing - it was great" (B, 02:47, Exercise 9). Other, more precisely detailed effects seem to be specific to the individual student, as when Desmond reaches the end of Exercise 8:

Congratulations. Now you see that's a different way of singing... You sang an $E$ flat, forward, but it also had a length at the front so it's very projected, and pretty "out there", you know. Very balanced as well because you've got the upper harmonic and the lower harmonic going at the same time. Great!

$(D, 10: 01)$

When the feedback is brief it sometimes means that Terrence has leapt ahead from diagnosis to prescription, as when he says "Yeah, not quite getting the pharynx; we'll, we'll work that now", leading directly into the next exercise (A, 06:38). There are other examples where feedback is diverted onto another course. In two incidents previously mentioned, the feedback is truncated when Terrence invites the student to join him in reflection - "Okay, so if we were to look at your voice, ah, overall, where's your strength and where's your weakness?" (B, 04:19); and "There you are, that's the top C; you seem to be covering the textures of the top and low really really well here. How are you feeling in yourself?..." (C, 06:50). In Lesson F Terrence goes further, using feedback more provocatively to frame a problem in Exercise 7. Student speech in this example is shown in italics:

Now you see that $\mathrm{G}$ is pretty good; I mean it's quite adequate - more than adequate. You see that it's sort of, it's not quite effulgent; it's not quite growing. Do you know what I'm saying?

Yes.

It's sort of like caught in a slot? It needs to go -

$(\mathrm{F}, 05: 49)$

This feedback leads directly into the next exercise, and the feedback for that develops the idea of being caught or - to use Faye's own word - "stuck" before leading directly on to yet another. Interestingly, the feedback for that, the final exercise in Lesson F, starts with only a single word of praise for what seems to have been an extended period of concentrated work - "Good" (F, 09:07, Exercise 9); but Faye, far from being discouraged, asserts herself into the feedback process.

Good, and so on. And it almost seems to be responding to the lean on your body a bit, better than last time? 
Yeah, I'm just absolutely like,

You're starting to -

I'm definitely thinking more about it, and how much it does support me... It's so important.

(F, 09:07)

This extract is abbreviated, and while Terrence's feedback becomes substantial, with a total of 72 words, the student contributes even more to the discussion, with 82 words. Faye's assertiveness is perhaps related to her seniority and ability: among the research participants, she is Terrence's "longest-serving" student, and she achieves High Distinction in her next performance examination. For the three students who are in their first year of study with Terrence, the teacher uses the final feedback in the exercise period to comment on broad progress. Esme is already an experienced student, but Terrence tells her, smilingly, that her voice is "Fifteen, fifteen and a half percent better than last week - seventeen going on twenty percent" (E, 10:53); Alyssa, according to the next examination marks, is the weakest student of the six, but Terrence's encouragement for her is strong:

Well, you have - you know - you've totally transformed in the last few weeks. See, what you were doing just there, just bears no resemblance to the person, the singer you were, in the first, ten weeks of this [semester]. Which is just amazing. Which shows, if you hang in there long enough, great things happen. If you just hang in there your technique, technical ability - see you were able to go forward there; you were able to go back, and you joined it up.

$(A, 17: 36)$

It might be noted that though the encouragement is strong, and words like "total" and "great" are presumably exaggeration, Terrence is scrupulously honest in his praise, gauging Alyssa's progress relative to her own trajectory; and in returning to previously discussed notions of going "forward" and "back", he is specific about what he is praising. Similarly perhaps, in the final feedback of the exercise period in Lesson B, Terrence spends 42 seconds summarising specific aspects of the work just done, illustrating his explanation with demonstration and gesture - "So that's a thing to think about" (B, 05:53).

\section{Discussion}

The first of the research questions in this paper sought the distinguishing characteristics of the exercise period or "warm-up" in advanced studio voice lessons. In the six lessons examined, the exercise period opens as matter of routine, without any preliminary discussion of the choice or order of content, though that kind of scope is made available in the later period devoted to repertoire. Relative to repertoire work, the exercise period has high levels of singing activity and low levels of verbal activity, while the asymmetry of lesson behaviour - the student dominating singing while the teacher dominates talk - is particularly marked. In each of the lessons the participants work through a core set of exercises, and while the student sings the teacher accompanies and directs from the piano, offering vocal, verbal, 
and gestural support. The period as a whole is one of high energy, with the intensity of coached singing driving toward the feedback that normally closes each exercise loop.

Having a core of exercises among the lessons might suggest a routine drill, but the inbuilt sequence of demands on the individual student - beginning with simple and relatively undemanding material and proceeding to more challenging work, with some personalised exploration - suggest processes of skill acquisition $(\mathrm{HOCH}$; SANDAGE, 2018) or voice building (NAFISI, 2013; O'BRYAN, 2015). In spite of some variety among the lessons, teacher and students generally approach the exercises through what has been described as a broadening spiral of activity: the later exercises are likely to involve more time, more singing and more talk, with the increase in wordage driven by more substantive feedback from the teacher. Examples have been described of multi-modal explanations for the last of the core exercises (Tables 7, 9), drawing on talk, demonstration and gesture; and as the students approach the limits of their personal stages of development, the teacher uses or improvises metaphorical gestures to represent the musical, psychomotor or imaginative concepts being learned.

The second research question was focused on the contributions of teacher and student to collaborative lesson behaviour. The question presupposed that lesson behaviour would be collaborative, though it was expected to be asymmetrical. The teacher Terrence dominates verbal dialogue in terms of wordage and in terms of the number and range of questions asked, and his behaviour particularly in coaching is highly directive. Howard acknowledges that "instruction is often portrayed as inherently authoritarian, not merely authoritative - a matter of blindly following orders" (1992, p. 66), and Uszler notes that authoritarianism is open to criticism, "notably by those who advocate learner-oriented teaching and by proponents of adult education" (1992, p.584). The function of authority however seems essential to the nature of the transaction in these exercise periods, with students effectively asked for, and granting, a good deal of trust in their instructor - hence Terrence's commendation of Desmond's "commitment" (D, 02:09). Howard, himself a serious singer as well as a philosopher of education, argues that "Far from being categorical morally or coercively, instructional commands are conditional and prudential in the sense of, 'If you want to learn how to do this well, then you must undertake the following'" (1992, p. 67).

What of the student's part in the collaboration? It could not be said that the students are inactive, and indeed in negotiating and often repeating the sequential exercises, complemented by dynamic and even athletic gestures, they are highly active. Perhaps the quality of their activity should be questioned in terms of reflection, a term borrowed from general education theory, as Williams et al. explain:

Reflection is a much over-used term within teacher education and space does not permit an analysis here of its various meanings. Suffice to say that reflection [refers] to aspects of mentor-student interaction which provoke thought on the part of students so that they are actively involved in their own learning rather than receiving information or guidance passively. (WILLIAMS et al., 1998, p. 229; emphasis original) 
It would be an exaggeration however to say that these students are passively accepting guidance, even if the exercises were to be regarded as routine drills: Howard points out that "even military recruits learning to slope arms must initially attend to the task as a precondition of its becoming automatic on command" (1992, p. 90-91). Neither should it be assumed that a predominance of nonverbal activity implies a lack of thought: even in general education settings, regarding verbal expression as the only evidence of engaged learning is problematic (REMEDIOS; CLARK; HAWTHORNE, 2008, p. 212). If the purpose of the exercise period or warm-up is skill acquisition, as indicated in the pedagogical materials described by Hoch and Sandage (2018), and if its use is particularly apt for students or pre-professional singers, as suggested by Elliot et al. (1995), then a significant role of exercise is to clarify and expand the blurry limits of the student's current competence. The very routine of the exercise period thus provides one of the "marvelous scaffolds for [mastering] complex behaviour" described by Shulman (2005, p. 56), and this implicates shared challenges and active collaboration.

Since the students' activity is dominated by performance and gesture, evidence of their understanding must be sought in their practical responses, and that is what Terrence does in the continual diagnosis and prescription of instruction. Evidence of his concern for their understanding is found in his use of questions - so often, by asking for a performed response, but also by asking simply whether they understand, adopting a querying tone in marking critical features, or inviting and supporting self-appraisal. It has been suggested that gesture is sometimes used metaphorically, particularly in dealing with concepts that lie near the limits of each student's current competence. Near those limits, too, Terrence sometimes uses feedback to frame problems - consistent with the principles of professional artistry (SCHÖN, 1987) and teacher attribution theory (KENNELL, 2002) - by identifying and characterising issues before going on to engage with them practically. Although there is only one instance among the exercise periods of the student himself identifying a problem - "What do you mean, a double Oh?" (D, 08:45) - it is clear from the teacher's response that the question is welcome; and it may be no coincidence that this, like Faye's enthusiastic contribution to the discussion of her own progress (F, 09:13), comes from a relatively senior student, who perhaps has acquired the know-how and confidence to participate in this way. Even the minor incident of Alyssa mistaking a demonstration for a cue, and accidentally interrupting it by joining in singing ( $A$, 0927), might be linked to her relatively junior status in Terrence's studio, recalling the notion that participating in a "signature pedagogy" (SHULMAN, 2005) is a skill in itself that must be acquired and internalised.

Terrence's support for the students' skill acquisition has been explored in terms of the third research question, focused on coaching and feedback. Coaching, delivered during exercise loops, has been divided among concise directions, reminders, encouragement and approval. Feedback, delivered at the end of each loop, sometimes overlaps coaching through the use of nonspecific praise, but the more idiomatic feedback is specific and often substantive. Brief, nonspecific praise is more likely to be given for the earlier exercises, which presumably have been routinized to a certain degree, while extended feedback is given for the later exercises, presumably areas of skill acquisition. 
Arguably, the teacher's scaffolding for extending the student's understanding and confidence may be seen at different stages of development as Terrence offers Alyssa an appraisal of her progress (A, 17:36), or invites Bree to self-appraise (B, 04:19), gives an expansive response to Desmond's question ( $D, 08: 45)$, or gives way to Faye's own reflections on her work ( $F, 09: 07)$.

Terrence's feedback for Alyssa is carefully gauged to encourage a relatively junior student and to appraise her of her progress to date, but all of the students receive feedback that is enthusiastically positive. Duke and Henninger (1998) argue that "approval" from the teacher may be less important in a context where students can perceive their own success through regular performance opportunities, but as singers cannot hear themselves as others hear them, and have inbuilt difficulties with self-monitoring, reassurance from the voice teacher may be particularly important. Callaghan, Emmons and Popeil explain that "vocalization is accompanied by bodily sensations, and singers must learn the particular body sensations associated with sounds that are aesthetically desirable and physically efficient" (2012, p. 567), and Kiik-Salupere and Ross add that "It is especially difficult for beginners to immediately find the correct coordinated feeling and to reproduce that feeling when required" $(2011$, p. 406). If the teacher's reassurance is linked to the element of "frustration control" in early scaffolding theories (WOOD; BRUNER; ROSS, 1976), then feedback has a double purpose - of providing emotional support, and helping the students learn to understand the progress being made, so that it can be more effectively made.

The complexity of the challenge for the student singer is matched by the challenge for the teacher in supporting her, as each strives to achieve a rapport of perception and understanding. Thus Howard refers to the "intersubjective judgement" involved, in "compensation for the unavoidable difference between hearing from 'within' and from 'without'" (1982, p. 90). Terrence responds to the challenge of meaningful communication verbally, through both technical language and imagery; vocally, by giving cues, reinforcement or demonstration; and gesturally, through cues indicating timing, conducting indicating expressive content, physical movements embedded in exercises, and metaphorical references to concepts that the student singer is encouraged to imagine. When Terrence gives what has been called a "multimodal explanation", the full range of communicative tools is implicated; and although the students rarely verbalise their understanding during the exercise periods, the degree of communication accomplished is evident in their vocal and gestural participation.

\section{Conclusion}

The broad aim of this paper has been to characterise the interaction between teacher and student as they engage in vocal teaching and learning in the exercise periods of advanced studio lessons. It is suggested that the characterisation represents an authentic possibility for advanced studio practices elsewhere, and for the voice studio in particular. There are obvious ways in which the generalisability of the study is limited, even in terms of the overall profile of a single teacher: this was a small number of les- 
sons, several of the lesson films are incomplete, and lesson behaviour appears to vary somewhat with individual students. The lesson films represent only a moment in the trajectories of the students, and offer no indication of how lessons might vary from one week to another. The teacher may be representative of a population of expert vocalists working in higher education, but there is presumably a good deal of variety within that sector; Terrence accompanies his own students at the piano, for example, but in other environments - perhaps better funded - it is taken for granted that an accompanist will be present, and this must have an effect on the dynamics of lesson behaviour (KIIK-SALUPERE; ROSS, 2011).

There are nevertheless features in the six lessons described that are consistent enough to suggest a coherent and regular approach, recalling aspects of the "signature pedagogies" described by Shulman (2005). The complexity of advanced vocal performance and the challenges of advanced vocal study are implicated in a multimodal collaboration between teacher and student, contributing in complementary ways to what may be a unique practice, though a similar intimacy of communication may be known perhaps to good chamber-music players. What may be unique, too, is the nature of instruction observed in the exercise period, which in spite of the collaborative features, is highly directive: indeed, it has been suggested that a high degree of direction is essential to the exercise work as it is conducted here. Although the degree may be peculiar to advanced voice teaching, the issue of authority is implicated in all studio practice, just as it is in apprenticeship; the exercise of authority in studio and apprenticeship practices must vary from one case to another, and it would be simplistic to assume that it must be either coercive or productive. The highly specialist context of the current case study, the productive nature of the lesson interactions, and the evident commitment of teacher and students in pursuing them, combine to suggest that advanced studio practices should be approached and understood on their own terms.

\section{References}

Association of European Conservatoires (AEC). Instrumental and vocal teacher education: European perspectives. Retrieved from http://www.polifonia-tn.org, 2010.

BENNETT, D. The use of learner-generated drawings in the development of music students' teacher identities. International Journal of Music Education, v.31, n.11, p.53-67, 2012.

BUNCH, M. Dynamics of the singing voice, 1st edn. Vienna: Springer, 2009.

BURWELL, K. A degree of independence: teachers' approaches to instrumental tuition in a university college. British Journal of Music Education, v.22, n.3, p.199-215, 2005.

BURWELL, K. Rich transcription. Exploring lesson interactions in higher education music. Scientia Paedagogica Experimentalis, v.47, n.2, p.305-331, 2010. 
BURWELL, K. Studio-based instrumental learning. Farnham: Ashgate, 2012.

BURWELL, K. 'She did miracles for me': an investigation of dissonant studio practices in higher education music. Psychology of Music, v.44, n.3, p.466-480, 2016a.

BURWELL, K. Dissonance in the studio: an exploration of tensions within the apprenticeship setting in higher education music. International Journal of Music Education, v.34, n.4, p.499-512, 2016b.

BURWELL, K. Issues of dissonance in advanced studio lessons. Research Studies in Music Education, p. 1-15. DOI: 10.1177/1321103X18771797, 2018.

BURWELL, K.; CAREY, G.; BENNETT, D. Isolation in studio music teaching: the secret garden. Arts \& Humanities in Higher Education, p.1-23. DOI: 10.1177/1474022217736581, 2017.

CALLAGHAN, J. Singing teachers and voice science - an evaluation of voice teaching in Australian tertiary institutions. Research Studies in Music Education, v.10, p.25-41, 1998.

CALLAGHAN, J.; EMMONS, S.; POPEIL, L. Solo voice pedagogy. In: MCPHERSON, G. E.; WELCH, G. F. (Eds). The Oxford handbook of music education. New York: Oxford University Press, 2012, v.1, p. 559-580. DOl:10.1093/oxfordhb/9780 199730810.013.0034.

CAREY, G. M. et al. Characterising one-to-one conservatoire teaching: some implications of a quantitative analysis. Music Education Research, v.15, n.3, p.357-368, 2013.

CAREY, G.; GRANT, C. Teacher and student perspectives on one-to-one pedagogy: practices and possibilities. British Journal of Music Education, v.32, n.1, p.5-22, 2015.

DAYME, M. Dynamics of the singing voice, 5th edn. Vienna: Springer, 2009.

DUKE, R. A.; HENNINGER, J. C. Effects of verbal corrections on student attitude and performance. Journal of Research in Music Education, v.46, n.4, p.482-495, 1998.

DUKE, R. A.; HENNINGER, J. C. Teachers' verbal corrections and observers' perceptions of teaching and learning. Journal of Research in Music Education, v.50, n.1, p.75-87, 2002.

DUKE, R. A.; SIMMONS, A. L. The nature of expertise: narrative descriptions of 19 common elements observed in the lessons of three renowned artist-teachers. Bulletin of the Council for Research in Music Education, v.170, p.7-19, 2006. 
ELLIOT, N.; SUNDBERG, J.; GRAMMING, P. What happens during vocal warm-up? Journal of Voice, v.9, n.1, p.37-44, 1995.

GAUNT, H. Promoting professional and paradigm reflection amongst conservatoire teachers in an international community. In: GAUNT, H.; WESTERLUND, H. (Eds.). Collaborative learning in higher music education: why what and how?. Farnham, Burlington: Ashgate, 2013, p.49-61.

GAUNT, H. One-to-one tuition in a conservatoire: The perceptions of instrumental and vocal teachers. Psychology of Music, v.36, n.2, p.215-245, 2008.

GISH, A. et al. J. Vocal warm-up practices and perceptions in vocalists: a pilot survey. Journal of Voice, v.26, n.1, p.1-10, 2012.

HOCH, M.; SANDAGE, M. J. Exercise science principles and the vocal warm-up: implications for singing voice pedagogy. Journal of Voice, p.79-84, 2018.

HOWARD, V. A. Artistry: the work of artists. Indianapolis: Hackett, 1982.

HOWARD, V.A. Learning by all means: lessons from the arts. A Study in the philosophy of education. New York: Peter Lang, 1992.

JAMES, M; WISE, K.; RINK, J. Exploring creativity in musical performance through lesson observation with video-recall interviews. Scientia Paedagogica Experimentalis, v.47, n.2, p.219-250, 2010.

JOHANSSON, K. Undergraduate students' ownership of musical learning: obstacles and options in one-to-one teaching. British Journal of Music Education, v.30, n.2, p.277295, 2013.

JØRGENSEN, H. Research into higher music education. An overview from a quality improvement perspective. Oslo: Novus, 2009.

JORGENSEN, M.; PHILLIPS, L. J. Discourse analysis as theory and method. London, Thousand Oaks, New Delhi: Sage, 2002.

KENNELL, R. Teaching music one-on-one: a case study. Dialogue in instrumental music education, v.21, n.1, p.69-81, 1997.

KENNELL, R. Systematic research in studio instruction in music. In: COLWELL, R.; RICHARDSON, C. (Eds.). The new handbook of research on music teaching and learning. New York: Oxford University Press, 2002, p.243-256. 
KENNELL, R. Mapping the use of scaffolding as a teacher intervention strategy in one-to-one music instruction. Scientia Paedagogica Experimentalis, v.47, n.2, p.281-304, 2010.

KIIK-SALUPERE, V.; ROSS, J. Tripartite unity: what students expect from their teacher and accompanist during individual singing lessons. Trames: A journal of the humanities and social sciences, v.15, n.4, p.404-421, 2011.

LAVE, J. The practice of learning. In: CHAIKLIN, S; LAVE, J (Eds.). Understanding practice. Perspectives on activity and context. Cambridge: Cambridge University Press, 1993, p.3-32.

MAXWELL, J. A. Using numbers in qualitative research. Qualitative Inquiry, v.16, p.475482, 2010.

MCPHAIL, G. J. Crossing boundaries: sharing concepts of music teaching from classroom to studio. Music Education Research, v.12, n.1, p.33-45, 2010.

MILLER, R. The structure of singing: system and art in vocal technique. Belmont: Wadsworth, 1986.

MOORCROFT, L.; KENNY, D. T. Vocal warm-up produces acoustic change in singers' vibrato rate. Journal of Voice, v.26, n.5, p.667, 2013a.

MOORCROFT, L.; KENNY, D. T. Singer and listener perception of vocal warm-up. Journal of Voice, v.27, n.2, p.258, 2013 b.

NAFISI, J. Gesture as a tool of communication in the teaching of singing. Australian Journal of Music Education, v.2, p.103-106, 2010.

NAFISI, J. Gesture and body-movement as teaching and learning tools in the classical voice lesson: a survey into current practice. British Journal of Music Education, v.30, n.3, p.347-367, 2013.

NERLAND, M. One-to-one teaching as cultural practice: two case studies from an academy of music. Music Education Research, v.9, n.3, p.399-416, 2007.

O'BRYAN, J. 'We ARE our instrument.' Forming a singer identity. Research Studies in Music Education, v.37, n 1, p.123-137, 2015.

PERÄKYLÄ, A. Reliability and validity in research based on tapes and transcripts. In: SILVERMAN, D. (Ed.). Qualitative research. Theory, method and practice. London, UK: Sage, 1997, p.201-220. 
RADLEY, A.; CHAMBERLAIN, K. The study of the case: conceptualising case study research. Journal of Community \& Applied Social Psychology, v.22, p.390-399, 2012.

REMEDIOS, L.; CLARKE, D.; HAWTHORNE, L. The silent participant in small group collaborative learning contexts. Active Learning in Higher Education, v.9, n.3, p.201-216, 2008.

SCHÖN, D. A. The reflective practitioner. How professional think in action. USA: Basic Books, 1983.

SCHÖN, D. A. Educating the reflective practitioner. Toward a new design for teaching and learning in the professions. San Francisco, London: Jossey-Bass, 1987.

SHULMAN, L. Signature pedagogies in the professions. Daedalus, v.134, p.52-59, 2005.

STAKE, R. E. Qualitative case studies. In: DENZIN, N. K.; LINCOLN, Y. S. (Eds.). The Sage handbook of qualitative research. Thousand Oaks: Sage, 2005, p.443-466.

TITZE, I. R. Vocal warm-ups: what do they accomplish? The Journal of the Acoustical Society of America, v.107, n.5, p.2864, 2000.

USZLER, M. Research on the teaching of keyboard music. In: COLWELL, R. (Ed). Handbook of research on music teaching and learning. New York: Schirmer Books, 1992, p.584-593.

WELCH, G. F.et al. Real-time feedback in the singing studio: an innovatory action-research project using new voice technology. Music Education Research, v.7, n.2, p.225249, 2005.

WEST, T.; ROSTVALL, A.-L. A study of interaction and learning in instrumental teaching. International Journal of Music Education, v.40, p. 16-29, 2003.

WILLIAMS, E.A.; BUTT, G.W.; GRAY, C.; LEACH, S.; MARR, A.; SOARES, A. (1998) Mentors' use of dialogue within a secondary initial teacher education partnership. Education Research, v.50, n.3, p.225-239, 1998.

WOOD, D.; BRUNER, J. S.; ROSS, G. The role of tutoring in problem solving. Journal of Child Psychology, v.17, n.89-100, 1976.

YIN, R. K. The abridged version of case study research. Design and method. In: BICKMAN, L.; ROG, D. J. (Eds.). Handbook of applied social research methods. Thousand Oaks: Sage, 1998, p.229-259. 